\title{
Potential Antifungal Activity of Two Plant Extracts and Jojoba Oil Against Fungi Causing Strawberry Crown and Root-Rots
}

\section{Elshaer, A.H.; Imara, D.A.; Soliman, M.S.; Khafagi, E.Y. and El-Nahas, S.E.M.}

Plant Pathology Research Institute, Agricultural Research Center, 12619, Giza, Egypt.

Tvaluation of the potential antifungal activity of some plant Eextracts as fungicides alternatives on the growth of some pathogenic fungi (Fusarium solani, Macrophomina phaseolina and Rhizoctonia solani) causing strawberry crown and root rots was studied under in vitro and in vivo conditions. The evaluated plant extracts were garlic and radish beside jojoba oil. Linear growth of the tested fungi was decreased significantly by all the tested plant extracts as well as by increasing their concentrations compared to control. The fungal growth was completely inhibited at concentration of $15 \%$ of both garlic and radish extracts in case of Macrophomina phaseolina and Rhizoctonia solani. All tested plant extracts reduced the disease severity of crown and root rots on strawberry in the nursery, decreased the percentage of dead transplants and increased growth parameters. Treatment of strawberry transplants with plant extracts and jojoba oil pre-planting in the field significantly reduced crown and root rot diseases severity, increased early and total yield, also increased total sugars, phenols and anthocyanin as well as increased fruit firmness compared to control treatment. It was noticed that using mixtures of plant extract (double or triple) gave better results than using each alone. The obtained results in the present study suggest that using plant extracts as fungicides alternatives could be a promising method in controlling strawberry soil borne pathogenic fungi.

Key words: Strawberry, crown rot, root rot, plant extracts, garlic, radish, jojoba oil

Strawberry (Fragaria xananassa Duch.) is one of the most important crops in many parts of the world and one of the major vegetable crops in Egypt. Diseases caused by soil-borne plant pathogens are the major problems in agricultural production throughout the world, reducing yield and quality of crops. Strawberry plants are attacked by several soil borne pathogens such as Fusarium spp., Rhizoctonia spp. and Macrophomina phaseolina, the causals of crown and root rots (Pastrana et al., 2014 Sanchez et al., 2016 and Errifi et al., 2019) which became severe and constant threat to strawberry cultivations, causing significant yield losses all over the country. These diseases became more widespread for many reasons 
including the withdrawal of methyl bromide as a soil fumigant except under very limited conditions. None of the remaining methods for soil fumigation is as effective, particularly for elimination of Fusarium spp. (El-Sharkawy, 2006).

Nowadays, it is well known that extensive and misuse of pesticides especially fungicides increase cost of the production, pollute the environment, being harmful to human health as well as emerging of numerous plant pathogens which have been observed to develop tolerance to chemical fungicides making the use of these chemicals ineffective. In the recent decade, several investigations tried to find alternative control methods, environmentally safe and easily biodegradable to reduce application of pesticides (Gnanamanickam, 2002; De Cal et al., 2004; Shaban, 2015 and Zaker, 2016). Plant extracts, essential oils, gums, resins etc. have been shown to exert biological activity against plant fungal pathogens in vitro and in vivo and can be used as bio-fungicidal products (Lozano et al., 2000; Jalili et al., 2010; Bhardwaj ,2012; Romanazzi et al., 2012 and Dewidar et al., 2019). These products are generally assumed to be more acceptable and less harmful for the environment and could be used as alternative methods for controlling plant diseases (Fawzi et al., 2009 and Romanazzi et al., 2012).

Extracts of garlic have been demonstrated to have antifungal properties against some pathogenic fungi (Singh, 2008). Mercado and Rodriguez (2001) treated two soil borne phytopathogens, i.e., R. solani and Myrothecium roridum with "Garlic Barrier" (a garlic compound) and found little effectiveness in reducing populations of either pathogen in culture. Garlic extract showed high suppressive effect on linear growth of $R$. solani and F. solani (Kuruchve and Padmavathi, 1997). Soaking peanut seeds in garlic extract before sowing decreased root-rot disease incidence incited by $M$. phaseolina and $R$. solani from $66.67 \%$ and $33.33 \%$ to $26.67 \%$ and $0.0 \%$, respectively (Osman et al. 1996). Adding garlic or onion aqueous extracts to soils infested with $R$. solani, M. phaseolina and $F$. oxysporum f. sp. vasinfectum greatly reduced pre- and post-emergence damping-off caused by these pathogens (Raja and Kurucheve, 1999).

Oil extract of jojoba seeds at different concentrations from"1 to $10 \%$ " gave good control against powdery mildew incidence on different plants (Hicks, 2001 and Reyad and Attia, 2016). Soliman et al., (2013) mentioned that using garlic and jojoba extracts under field conditions as seed treatment at the concentration $3 \%$ significantly reduced disease incidence and also increased the percentage of yield components, i.e., the number and weight of pods/plant and dry weight of 100 seeds followed by jojoba extracts. Garlic and jojoba were the most effective extracts since they recorded the highest plant stand and the best yield components in comparison with the control.

Extract of radish (Raphanus sativus) is previously stated with a wide range of metabolites with regard to biopharmaceuticals and bio pesticides (Singh and Singh,

Egypt. J. Phytopathol., Vol. 47, No. 2 (2019) 
2013 and Javaid and Bashir, 2015 and Hassan et al., 2016). Seeds and aerial parts of radish have been long known for their strong antifungal and antibacterial activity due to the presence of the raphanin compound and they have also been analyzed individually for antimicrobial activity and was found to be active against many pathogens. Seeds of radish are rich source of chemical compounds like phenols, alkaloids, glycosides and sterols, these compounds are believed to be potential against several pathogenic microbes (Gutiérrez and Perez, 2004; Rani et al., 2008 and Hassan et al., 2016).

This study aimed to reduce the consequences of using fungicides by searching for an alternative control method such as using plant extracts. So the objectives of this study were to: (1) evaluate the effects of natural extracts of garlic and radish in addition to jojoba oil on inhibiting mycelial growth of Fusarium solani, Macrophomina phaseolina and Rhizoctonia solani, the causals of strawberry crown and root rots, in lab assays, (2) determine the effectiveness of these natural products singly or in combinations on suppression of the above mentioned fungal pathogens and developing plant quality characters in nursery and field experiments.

\section{Materials and Methods}

Pathogenic fungi:

Virulent pathogenic fungal isolates, Fusarium solani, Rhizoctonia solani and Macrophomina phaseolina obtained from Mycology Research \& Diseases Survey Department, Plant Pathology Research Institute, Agricultural Research Center, Egypt were used in the present investigation. These isolates proved their pathogenic ability to induce crown and root rot disease to strawberry plants in previous studies (Mosa et al., 2013).

Effect of plant extracts on the linear growth of the tested pathogenic fungi under laboratory conditions:

Extracts of garlic (Allium sativum L.) cloves, radish (Raphanus sativus L.) seeds and jojoba (Simmondsi achinensis L.) oil were tested for their ability to inhibit mycelial growth of the pathogenic fungi, Fusarium solani, Macrophomina phaseolina and Rhizoctonia solani under lab conditions. Jojoba oil was obtained commercially from Elgarhy Pharmacy, Cairo, Egypt. Garlic cloves and radish seeds (previously grinded) extracts were prepared by mixing $250 \mathrm{~g}$ from each to 1 -liter distilled water then blended in an electric blender for 5 minutes. The extracts were filtered through double layers of cheesecloth (Tohamy et al., 2002). The filtered plant extracts were centrifuged at $3000 \mathrm{rpm}$ for 10 minutes, sterilized by passing through centered glass sterilized funnel (G5) then added individually to flasks containing sterilized PDA medium before solidification to obtain concentrations of 5, 10 and $15 \%$. Jojoba oil was mixed thoroughly with Tween 80 at conc. $0.3 \%$ before adding to the medium. Flasks containing plain PDA were served as control treatments. Supplemented and free media were poured into $9 \mathrm{~cm}$ Petri dishes. The 
plates were individually inoculated at the center with equal disks $(5 \mathrm{~mm})$ of 7-day old culture of the tested fungi. Three plates were used as replicates for each particular treatment. Inoculated plates were incubated at $25 \pm 2^{\circ} \mathrm{C}$ in dark. The average linear growth of the tested fungi was calculated when controls reached full growth then percentage of reduction in mycelial growth was calculated in relative to check treatment according to Fokemma (1973) equation:

$$
\text { Reduction percentage }=(\mathrm{C}-\mathrm{T}) / \mathrm{C} \times 100
$$

Whereas: $\quad \mathrm{C}=$ Maximum linear growth in control.

$$
\mathrm{T}=\text { Maximum linear growth in treatment. }
$$

\section{Nursery and Field experiments:}

Nursery and field experiments were carried out at Kafr Al-Sohby, Qaloubiya governorate during seasons 2017/2018 and 2018/2019 in naturally infested soil with the tested pathogenic fungi and the incidence of strawberry root rot occurs regularly every year (Shehata, 2007). Strawberry cultivar festival was used in these experiments during both seasons.

\section{Treatments in the nursery:}

Eight treatments were investigated in the nursery as follows: 1) garlic extract, 2) jojoba oil, 3) radish extract 4) garlic extract + radish extract, 5) garlic extract + jojoba oil, 6) garlic extract + radish extract+ jojoba oil, 7) fungicides:(a mixture of Rizolex T 50\% [Tolclofos-methyl + thiram] 1g/l+ Tachigaren 30\% [Hymexazol] $1 \mathrm{ml} / 1$ + Topsin M $70 \%$ [Thiophanate methyl] $1 \mathrm{~g} / \mathrm{l}$, mixed at ratio1:1:1 v $(50 \mathrm{ml}$ /transplant) and 8) control (untreated). Strawberry transplants cv. Festival (one month old) were used in this experiment. In mid-April in each season, (2017/2018 and 2018/2019), transplants were grown in the nursery in rows $1.5 \times 1.5 \mathrm{~m}$ space. Plant extracts and jojoba oil (singly or mixture) were applied as soil drench to each transplant at the rate of $15 \%$ conc. $(15 \mathrm{ml}$ plant extract or jojoba oil $/ 100 \mathrm{ml}$ water were used for each transplant). Each of the afore mentioned treatments was applied three times during nursery stage, with 30 days' intervals. By the end of nursery stage, plants were collected and transferred to the field to be used as transplants. The plants were tested visually and categorized as healthy and diseased during transplanting process in addition, some growth parameters were estimated i.e., number of lateral roots, root length and crown diameter. Disease severity was evaluated as the ratio of infected area of the crowns and roots to the whole crown or root using disease index of 11 categories according to the following equation (Horsfall and Barratt ,1945):

Sum (No. each infection category $\mathrm{x}$ Numeral value of

$$
\text { Disease severity }(\%)=\frac{\text { infection category) }}{\text { Total no. of crowns or roots } x \text { Highest numerical value }} \times 100
$$

Where: 0 to 11 categories represent $1=0,2=0-3 \%, 3=3-6 \%, 4=6-12 \%, 5=12-25 \%$, $6=25-50 \%, 7=50-75 \%, 8=75-87 \%, 9=87-94 \%, 10=94-97 \%, 11=97-100 \%$ and $12=100 \%$ area diseased, respectively to categorize severity.

Egypt. J. Phytopathol., Vol. 47, No. 2 (2019) 
Field experiment:

Healthy strawberry transplants emerged from treated nursery were selected for field experiments. All experiments were conducted in a complete randomized block design with three replicated plots. Transplants were planted in rows, $50 \mathrm{~cm}$ apart and $30 \mathrm{~cm}$ between each other in the row. The aforementioned treatments in the nursery were applied again with the same used concentration once in planting time. Strawberry transplants (cv. Festival) were soaked in plant extracts, jojoba oil (singly or in combination), and the mixture of fungicides just before planting for 20 minutes. The early fruits yield was evaluated after 60 days from transplanting. Then after another 60 days strawberries were harvested to evaluate the total yield. Disease severity on crowns and roots were evaluated at the end of the growing season. Strawberry samples from each treatment were collected for chemical analysis.

Chemical analysis of the collected fruits:

Extraction was done using Soxhlet units by putting the macerated tissues (Ten grams of strawberry fruits from each treatment) in the units and using $75 \%$ ethanol $(100 \mathrm{ml})$ in the extraction process. The process took $12 \mathrm{~h}$ till complete evaporation of the ethanol under room temperature $\left(22-24^{\circ} \mathrm{C}\right)$. The residual precipitate was then dissolved in $5 \mathrm{ml}$ of $50 \%$ isopropanol and kept in $-20^{\circ} \mathrm{C}$ until use.

Total sugars:

Total sugars content in strawberry fruits was evaluated following the method described by Thomas and Dutcher (1924).

Total and free phenols:

Total and free phenol contents were determined according to the method described by Simons and Ross (1971). The analysis was performed in three replicates for each treatment. Phenol content was measured as $\mathrm{mg} / \mathrm{g}$ fresh weight.

Determination of anthocyanins:

According to the method described by Fuleki and Francis, 1968 anthocyanins pigments of strawberry extraction from fruits in each treatment was done. The analysis was performed in three replicates for each treatment.

Firmness:

Firmness of strawberry fruits was determined according to (Burkhart, 1943) using fruit pressure tester (handheld penetrometer), plunger size $(0.5 \mathrm{~cm}$ diameter), fruit firmness was measured as Newton $(\mathrm{N})$

Statistical analysis:

All experiments were conducted in a complete randomized block design with three replicates. All the obtained data were subjected to statistical analysis and compared according to the least significant difference (L.S.D) as mentioned by Snedecor and Cochran (1989). Linear correlation coefficient (r) was used to evaluate 
the relationship between symptoms, early yield and biochemical variables. Statistical analysis was performed with the software package SPSS 10.0.

\section{Results}

Effect of plant extracts on the linear growth of the tested fungi under laboratory conditions:

This experiment was conducted to evaluate the antifungal effect of the tested plant extracts on inhibiting the mycelial growth of the pathogenic fungi affecting strawberry plants. Data illustrated in Fig. (1) indicate that all the tested plants extracts significantly decreased the mycelial growth of the pathogenic fungi compared to control treatment. It was noticed that the reduction was gradually increased by increasing plant extracts concentrations. At $15 \%$ conc. radish and garlic extracts were the best ones in inhibiting most of the tested fungi, M. phaseolina and $R$. solani as it gave $100 \%$ reduction. According to the efficacy mean, radish extract came first $(93.1 \%)$ followed by garlic extract $(92.9 \%)$ whereas, jojoba oil was the least in this effect $(81.8 \%)$. Also, between the fungi tested $F$. solani was the least affected by the tested solutions at all the tested concentrations.

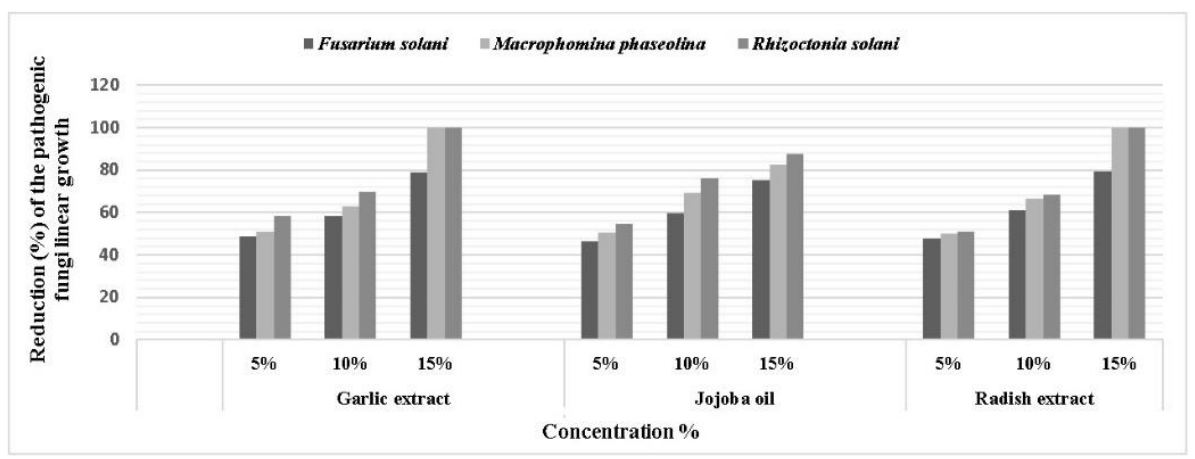

Fig. (1): Effect of the two tested plant extracts (garlic and radish) and jojoba oil on the mycelial growth of the pathogenic fungi causing strawberry crown and root rots.

Effect of treating strawberry transplants with plant extracts and Jojoba oil in the nursery on disease severity during two seasons:

Data presented in Table (1) reveal that all the tested plant extracts and jojoba oil significantly reduced disease severity on crown and root compared to control treatment. Meanwhile, the same trend was noticed during the two growing seasons. Although fungicides treatment was the most effective in reducing disease severity, it was clear that combining plant extracts and jojoba oil gave remarkable effect in decreasing disease severity of both diseases. Treatment where the two plant extracts were combined with jojoba oil gave the highest effect compared with any of the treatments. At the same time, it was noticed that in the second season the level of

Egypt. J. Phytopathol., Vol. 47, No. 2 (2019) 
reduction in disease severity showed almost the same pattern of the first season with slight increase.

Table (1): Effect of garlic and radish extracts and jojoba oil on the disease severity of strawberry crown and root rots in the nursery during the two successive seasons 2017/18 and 2018/19.

\begin{tabular}{|l|c|c|c|c|}
\hline \multirow{2}{*}{\multicolumn{2}{|c|}{ Treatment }} & \multicolumn{4}{c|}{ \% Disease severity } \\
\cline { 2 - 5 } & \multicolumn{2}{|c|}{$2017 / 18$} & \multicolumn{2}{c|}{$2018 / 19$} \\
\cline { 2 - 5 } & Crown rot & Root rot & Crown rot & Root rot \\
\hline Garlic extract & 9.1 & 12.0 & 7.5 & 9.6 \\
\hline Jojoba oil & 13.3 & 15.7 & 11.6 & 13.3 \\
\hline Radish extract & 11.7 & 13.3 & 9.4 & 11.7 \\
\hline Garlic extract + Jojoba oil & 7.8 & 9.6 & 6.3 & 8.5 \\
\hline Garlic extract + Radish extract & 6.2 & 8.2 & 5.2 & 7.5 \\
\hline Garlic extract + Jojoba oil+ Radish extract & 4.1 & 6.2 & 3.5 & 5.0 \\
\hline Fungicides* & 1.5 & 2.8 & 1.4 & 1.9 \\
\hline Control & 33.0 & 36.4 & 35.0 & 40.0 \\
\hline L.S.D at 5\% & 1.73 & 1.23 & 1.55 & 1.98 \\
\hline
\end{tabular}

*Fungicides used were a mixture of Rizolex T, Tachigaren and Topsin M

Before transmitting the transplants from the nursery to the field, they were examined to pick the healthy ones for transplanting in the field. Data illustrated in Fig (2) show that plant extracts and jojoba oil which reduced disease severity of crown and root rots also reduced significantly the percentage of diseased transplants and gave the highest number of visually healthy transplants compared to control. Fungicides were the most effective treatment followed by the treatment in which two plant extracts plus jojoba oil were combined. Also the least effective treatment was that when jojoba oil was used alone.

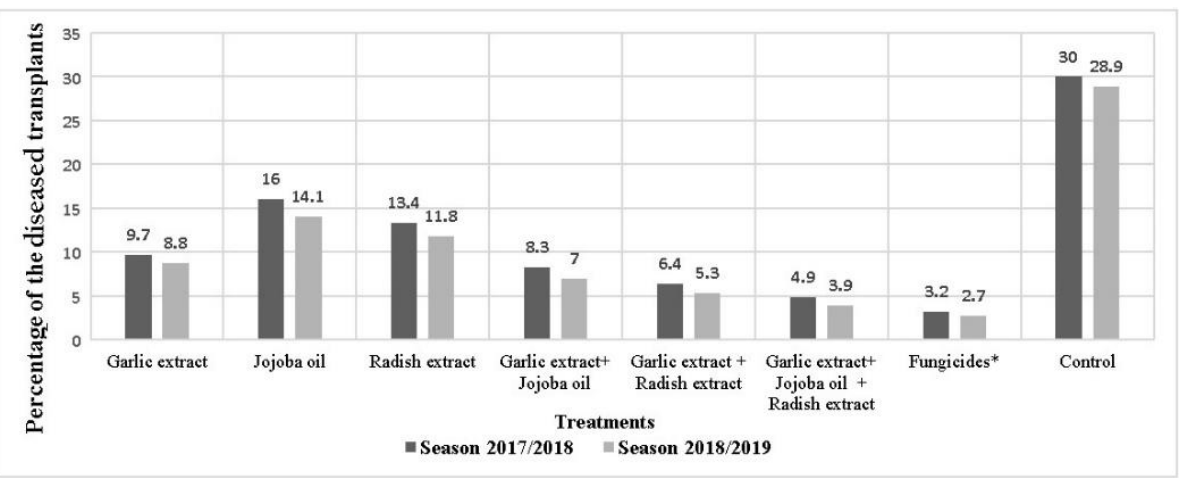

Fig (2): Effect of treating strawberry transplants with two plant extracts (garlic and radish) and jojoba oil on number of diseased transplants produced from the nursery of strawberry during the two successive seasons 2017/18 and 2018/19.

Egypt. J. Phytopathol., Vol. 47, No. 2 (2019) 
Effect of treating strawberry transplants with different plant extracts on some growth parameters:

Data in Table (2) represent the effect of drenching soil of strawberry transplants in the nursery with the two different plant extracts and jojoba oil on some growth parameters during two seasons. Data reveal that all the plant extracts and jojoba oil had significant effect on plant growth. Noticeably, fungicides had the major effect on all the growth parameters [number of lateral roots, root length $(\mathrm{cm})$ and crown diameter $(\mathrm{mm})]$ during the two seasons. Secondly came the combination of plant extracts and jojoba oil treatment during the two seasons since the number of lateral roots, root length and crown diameter were increased almost 5 folds compared to control. At the same time, the increase in crown diameter was significant in all treatments compared to control. Generally, combining plant extracts and jojoba oil gave better results than using each alone.

Table (2): Effect of plant extracts and jojoba oil on some growth parameters of produced strawberry plants during the two successive seasons 2017/18 and 2018/19.

\begin{tabular}{|l|c|c|c|c|c|c|}
\hline \multirow{2}{*}{ Treatment } & \multicolumn{3}{|c|}{$2017 / 18$} & \multicolumn{3}{c|}{$2018 / 19$} \\
\cline { 2 - 7 } & $\begin{array}{c}\text { No. of } \\
\text { lateral } \\
\text { roots }\end{array}$ & $\begin{array}{c}\text { Root } \\
\text { length } \\
\text { (cm) }\end{array}$ & $\begin{array}{c}\text { Crown } \\
\text { diameter } \\
(\mathrm{mm})\end{array}$ & $\begin{array}{c}\text { No. of } \\
\text { roots }\end{array}$ & $\begin{array}{c}\text { Root } \\
\text { length } \\
(\mathrm{cm})\end{array}$ & $\begin{array}{c}\text { Crown } \\
\text { diameter } \\
(\mathrm{mm})\end{array}$ \\
\hline Garlic extract & 26 & 19.5 & 10 & 29 & 21.0 & 11 \\
\hline Jojoba oil & 17 & 15.4 & 7 & 22 & 16.5 & 8 \\
\hline Radish extract & 22 & 17.6 & 9 & 25 & 19.5 & 10 \\
\hline Garlic extract + Jojoba oil & 29 & 21.4 & 11 & 34 & 23.0 & 12 \\
\hline Garlic extract + Radish extract & 33 & 25.3 & 13 & 36 & 27.5 & 14 \\
\hline $\begin{array}{l}\text { Garlic extract + Jojoba oil + } \\
\text { Radish extract }\end{array}$ & 35 & 28.0 & 15 & 39 & 30.5 & 16 \\
\hline Fungicides* & 45 & 35.6 & 18 & 48 & 38.5 & 19 \\
\hline Control & 5 & 4.5 & 4 & 4 & 5.5 & 3 \\
\hline L.S.D. at 5\% & 5.36 & 2.17 & 1.73 & 2.81 & 8.78 & 2.14 \\
\hline
\end{tabular}

*Fungicides used were a mixture of Rizolex T, Tachigaren and Topsin M

Effect of treating strawberry transplants with two plant extracts and jojoba oil under the field conditions during two successive growing seasons on:

A- Crown and root rots disease severity:

Data concerning the effect of plant extracts treatments singly or in combination on disease severity of strawberry crown and root rots in the field are presented in Table (3). There was a significant reduction in disease severity on root rot and crown rot due to all treatments compared to control during the two successive growing seasons. Generally, fungicides gave the highest reduction in disease severity in both

Egypt. J. Phytopathol., Vol. 47, No. 2 (2019) 
seasons. The two tested plant extracts combined with jojoba oil improved their ability to reduce disease severity with root rot and crown rot compared to using each treatment alone. In single treatments, garlic extract occupied the first rank in this respect since it gave 6.2 and $8.5 \%$ disease severity of crown rot and root rot, respectively in the first season and 4.7, 7.5\%, respectively in the second season. Meanwhile, treatments with radish extract and jojoba oil were the least in this respect. It was also noticed that the reduction in disease severity was higher in the second season than in the first one.

Table (3): Effect of plant extracts and jojoba oil on disease severity (\%) of strawberry (cv. Festival) crown and root rots in the field during the two successive seasons 2017/18 and 2018/19.

\begin{tabular}{|c|c|c|c|c|}
\hline \multirow{3}{*}{ Treatment } & \multicolumn{4}{|c|}{$\%$ Disease severity } \\
\hline & \multicolumn{2}{|c|}{$2017 / 18$} & \multicolumn{2}{|c|}{$2018 / 19$} \\
\hline & $\begin{array}{c}\text { Crown } \\
\text { rot }\end{array}$ & Root rot & $\begin{array}{c}\text { Crown } \\
\text { rot }\end{array}$ & Root rot \\
\hline Garlic extract & 6.2 & 8.5 & 4.7 & 7.5 \\
\hline Jojoba oil & 7.5 & 11.7 & 6.6 & 9.4 \\
\hline Radish extract & 6.6 & 9.4 & 5.0 & 8.2 \\
\hline Garlic extract + Jojoba oil & 4.9 & 6.6 & 3.8 & 6.2 \\
\hline Garlic extract + Radish extract & 3.5 & 4.7 & 2.0 & 3.5 \\
\hline Garlic extract + Jojoba oil + Radish extract & 2.8 & 3.5 & 1.5 & 2.8 \\
\hline Fungicides* & 1.5 & 1.9 & 0.6 & 0.9 \\
\hline Control & 25.0 & 30.3 & 32.0 & 37.0 \\
\hline L.S.D. at $5 \%$ & 1.3 & 0.7 & 0.9 & 1.7 \\
\hline
\end{tabular}

*Fungicides used were a mixture of Rizolex T, Tachigaren and Topsin M

\section{$B$ - Early and total yield production of strawberry:}

Effect of treating strawberry transplants with plant extracts and jojoba oil on the early and total yield production of fruits was evaluated. Data presented in Table (4) reveal that in general both early and total yield were increased significantly with all the tested treatments compared to control and that was the same in both seasons. The fungicides treatment was the most effective in increasing both early and total yield followed by mixing plant extracts with jojoba oil (Table 4). In case of using single plant extracts, garlic extract was the best in increasing both early and total yield giving $11.5 \mathrm{~kg}$ and $55.5 \mathrm{~kg}$, respectively in the first season and $13 \mathrm{~kg}$ and $61.5 \mathrm{~kg}$ in the second season followed by radish extract. Jojoba oil was the least effective one in this respect. 
Table (4): Effect of plant extracts and jojoba oil on strawberry early and total fruit yield during the two successive seasons 2017/18 and 2018/19.

\begin{tabular}{|l|c|c|c|c|}
\hline \multirow{2}{*}{\multicolumn{2}{|c|}{ Treatment }} & \multicolumn{2}{c|}{$2017 / 18$} & \multicolumn{2}{c|}{$2018 / 19$} \\
\cline { 2 - 5 } & $\begin{array}{c}\text { Early } \\
\text { yield } \\
\left(\mathrm{kg} / 21 \mathrm{~m}^{2}\right)\end{array}$ & $\begin{array}{c}\text { Total } \\
\text { yield } \\
\left(\mathrm{kg} / 21 \mathrm{~m}^{2}\right)\end{array}$ & $\begin{array}{c}\text { Early } \\
\text { yield } \\
\left(\mathrm{kg} / 21 \mathrm{~m}^{2}\right)\end{array}$ & $\begin{array}{c}\text { Total } \\
\text { yield } \\
\left(\mathrm{kg} / 21 \mathrm{~m}^{2}\right)\end{array}$ \\
\hline Garlic extract & 11.5 & 55.5 & 13 & 61.5 \\
\hline Jojoba oil & 7.5 & 42 & 8.5 & 47.5 \\
\hline Radish extract & 8.5 & 44.5 & 11.0 & 50.5 \\
\hline Garlic extract + Jojoba oil & 13.0 & 65.0 & 14.5 & 70.5 \\
\hline Garlic extract + Radish extract & 14.5 & 75.5 & 16.5 & 80.5 \\
\hline $\begin{array}{l}\text { Garlic extract + Jojoba oil + Radish } \\
\text { extract }\end{array}$ & 16.5 & 91.5 & 18.5 & 97.5 \\
\hline Fungicides* & 23.0 & 110.0 & 25.0 & 120.0 \\
\hline Control & 4.5 & 22.0 & 4.0 & 20.0 \\
\hline L.S.D. at 5\% & 2.12 & 5.76 & 2.87 & 5.94 \\
\hline
\end{tabular}

*Fungicides used were a mixture of Rizolex T, Tachigaren and Topsin M

\section{Chemical analysis:}

It was noticed from data in Table (5) that treatments significantly increased total sugars contents in strawberry fruits compared to control although they varied in their effect, that was obvious in the first season. The most effective treatment in increasing sugar was when garlic extract was applied alone giving $7.65 \mathrm{mg} / \mathrm{g}$ followed by radish extract on the average without significant differences giving 7.18 $\mathrm{mg} / \mathrm{g}$. On the other hand, in second season total content of sugar was decreased in the fruits in all treatments. In case of fruit firmness, there was no significance among the treatments in the first season. Similarly, the effect of the different treatments on fruit firmness was generally insignificant in the second season. In case of anthocyanins, it was noticed that treatments varied in their effect in this respect. In general, some treatments increased anthocyanin content significantly compared to control. The most effective one was applying radish extract singly followed by mixing all plant extracts treatment. However, in the second year the improvement in anthocyanins was insignificant.

\section{Phenolic content of strawberry fruits:}

Data presented in Table (6) reveal that there were remarkable variations between the two seasons in case of total and free phenols content. In the first season, radish extract was the best treatment in significantly increasing total phenol content giving $4.933 \mathrm{mg} / \mathrm{g}$ followed by fungicides and garlic extract treatments with corresponding values 3.715 and $3.044 \mathrm{mg} / \mathrm{g}$, respectively. On contrary, total phenols were generally decreased in the second season compared to control although in some cases the decrease was insignificant. Also, in the second season, treatment with radish extract caused significant increase in total phenols. Similarly, free phenols were increased

Egypt. J. Phytopathol., Vol. 47, No. 2 (2019) 
significantly due to all treatments in the second season. The best increase was in case of mixing the two plant extracts with jojoba oil followed by mixing garlic and radish extracts.

Table (5): Effect of soaking strawberry transplants in plant extracts and jojoba oil as well as fungicides on the content of anthocyanins, fruit firmness, and total sugar in strawberry fruit formed on treated plants during the two successive seasons 2017/18 and 2018/19.

\begin{tabular}{|l|c|c|c|c|c|c|}
\hline \multirow{2}{*}{ Treatment } & \multicolumn{3}{|c|}{$2017 / 18$} & \multicolumn{3}{c|}{$2018 / 19$} \\
\cline { 2 - 7 } & $\begin{array}{c}\text { Anthocya } \\
\text { nins } \\
(\mathrm{mg} / \mathrm{g})\end{array}$ & $\begin{array}{c}\text { Fruit } \\
\text { firmness } \\
(\mathrm{N})\end{array}$ & $\begin{array}{c}\text { Total } \\
\text { sugars } \\
(\mathrm{mg} / \mathrm{g})\end{array}$ & $\begin{array}{c}\text { Anthocya } \\
\text { nins } \\
(\mathrm{mg} / \mathrm{g})\end{array}$ & $\begin{array}{c}\text { Fruit } \\
\text { firmness } \\
(\mathrm{N})\end{array}$ & $\begin{array}{c}\text { Total } \\
\text { sugars } \\
(\mathrm{mg} / \mathrm{g})\end{array}$ \\
\hline Garlic extract & 10.10 & 27.85 & 7.65 & 5.72 & 8.80 & 3.62 \\
\hline Jojoba oil & 10.23 & 26.99 & 5.71 & 6.28 & 10.79 & 3.66 \\
\hline Radish extract & 11.48 & 23.00 & 7.18 & 6.13 & 12.76 & 4.01 \\
\hline Garlic extract + Jojoba oil & 10.11 & 24.51 & 7.13 & 6.24 & 10.64 & 3.39 \\
\hline Garlic extract + Radish extract & 9.33 & 22.65 & 5.04 & 6.16 & 10.31 & 3.30 \\
\hline Garlic extract + Jojoba oil + \\
Radish extract & 10.42 & 26.40 & 5.55 & 6.61 & 11.44 & 3.49 \\
\hline Fungicides* & 9.44 & 23.47 & 6.96 & 6.43 & 10.64 & 4.94 \\
\hline Control & 3.34 & 19.93 & 4.06 & 2.70 & 5.49 & 2.35 \\
\hline L.S.D. at 5\% & 2.23 & 5.88 & 1.22 & 1.06 & 2.55 & 1.15 \\
\hline
\end{tabular}

*Fungicides used were a mixture of Rizolex T, Tachigaren and Topsin M

Table (6): Effect of soaking strawberry transplants in plant extracts and jojoba oil as well as fungicides on total and free phenol contents in strawberry fruit formed on treated plants during the two successive seasons 2017/18 and 2018/19.

\begin{tabular}{|l|c|c|c|c|}
\hline \multirow{2}{*}{\multicolumn{2}{|c|}{ Treatment }} & \multicolumn{2}{c|}{$2017 / 18$} & \multicolumn{2}{c|}{$2018 / 19$} \\
\cline { 2 - 5 } & $\begin{array}{c}\text { Total } \\
\text { phenols } \\
\mathrm{mg} / \mathrm{g}\end{array}$ & $\begin{array}{c}\text { Free } \\
\text { phenols } \\
\mathrm{mg} / \mathrm{g}\end{array}$ & $\begin{array}{c}\text { Total } \\
\text { phenols } \\
\mathrm{mg} / \mathrm{g}\end{array}$ & $\begin{array}{c}\text { Free } \\
\text { phenols } \\
\mathrm{mg} / \mathrm{g}\end{array}$ \\
\hline Garlic extract & 3.044 & 1.225 & 12.538 & 8.819 \\
\hline Jojoba oil & 2.789 & 1.513 & 14.574 & 10.161 \\
\hline Radish extract & 4.933 & 1.426 & 22.123 & 10.391 \\
\hline Garlic extract + Jojoba oil & 2.715 & 1.737 & 14.382 & 10.049 \\
\hline Garlic extract + Radish extract & 2.423 & 1.863 & 13.786 & 10.862 \\
\hline Garlic extract + Jojoba oil + Radish extract & 2.544 & 1.593 & 14.234 & 11.058 \\
\hline Fungicides* & 3.715 & 2.996 & 14.541 & 8.109 \\
\hline Control & 2.452 & 1.954 & 16.516 & 6.882 \\
\hline L.S.D. at 5\% & 2.19 & 0.24 & 5.12 & 1.67 \\
\hline
\end{tabular}

*Fungicides used are a mixture of Rizolex T, Tachigaren and Topsin M 
Data in Table (7) reveal that there was a correlation between the disease severity on roots rot, early yield and total phenol content. Correlation coefficient of the disease severity $(\%)$ with early harvest for the first and the second season was $((\mathrm{r}=-$ $0.797, \mathrm{p}=0.018)$ and $(\mathrm{r}=-0.791, \mathrm{p}=0.019))$ respectively. Also, low correlation coefficients of the disease severity $(\%)$ with the total phenolic content were $((\mathrm{r}=-$ $0.209, \mathrm{p}=0.620)$ and $(\mathrm{r}=-0.218, \mathrm{p}=0.605))$ respectively. On the other hand, significant positive correlation was noticed between disease severity on root and early yield in the first and the second season, being $((\mathrm{r}=-0.797, \mathrm{p}=0.018)$ and $(\mathrm{r}=$ $0.791, \mathrm{p}=0.019)$ ) respectively. The disease severity on root was inversely proportional with early harvest.

Table (7): Correlation between disease severity of root rot, early harvest and total phenolic content of strawberry fruits.

\begin{tabular}{|l|c|c|c|c|c|c|}
\hline \multirow{2}{*}{ variables } & \multicolumn{3}{|c|}{$2017 / 18$} & \multicolumn{2}{c|}{$2018 / 19$} \\
\cline { 2 - 7 } & $\begin{array}{c}\text { Disease } \\
\text { severity } \\
\text { on root }\end{array}$ & $\begin{array}{c}\text { Early } \\
\text { yield }\end{array}$ & $\begin{array}{c}\text { Total } \\
\text { phenol }\end{array}$ & $\begin{array}{c}\text { Disease } \\
\text { severity } \\
\text { on root }\end{array}$ & $\begin{array}{c}\text { Early } \\
\text { yield }\end{array}$ & $\begin{array}{c}\text { Total } \\
\text { phenol }\end{array}$ \\
\hline Disease severity on root & - & - & - & - & - & - \\
\hline Early yield & - & - & - & $-0.791^{* a}$ & & $-019^{\mathrm{b}}$ \\
\hline Total phenolic content & $\begin{array}{c}0.797^{\mathrm{a} a} \\
.018^{\mathrm{b}}\end{array}$ & $-0.209^{\mathrm{a}}$ \\
$0.620^{\mathrm{b}}$ & $-0.061^{\mathrm{a}}$ & $0.886^{\mathrm{b}}$ & - & $\begin{array}{c}-0.218^{\mathrm{a}} \\
0.605^{\mathrm{b}}\end{array}$ & $\begin{array}{c}-0.025^{\mathrm{a}} \\
0.953^{\mathrm{b}}\end{array}$ & - \\
\hline
\end{tabular}

a linear correlation coefficient(r) is significant at the 0.05 level, ${ }^{\mathrm{b}}$ probability level.

Coefficients of correlation between the disease severity of crown rot, early harvest and total phenolic content are presented in Table (8). Data reveal that the disease severity on crown recorded under field conditions was significantly correlated with early harvest in the first season, being $(r=-0.747, p=0.033)$. The same trend was observed in the second season. On the other hand, there was a correlation between disease severity of crown and total phenolic content of strawberry fruit in both two seasons.

Table (8): Coefficients of correlation between disease severity on crown, early harvest and total phenol of strawberry fruits.

\begin{tabular}{|c|c|c|c|c|c|c|}
\hline \multirow[b]{2}{*}{ Variables } & \multicolumn{3}{|c|}{$2017 / 18$} & \multicolumn{3}{|c|}{$2018 / 19$} \\
\hline & $\begin{array}{c}\text { Disease } \\
\text { severity on } \\
\text { crown } \\
\end{array}$ & $\begin{array}{l}\text { Early } \\
\text { yield }\end{array}$ & $\begin{array}{c}\text { Total } \\
\text { phenol }\end{array}$ & $\begin{array}{c}\text { Disease } \\
\text { severity } \\
\text { on crown } \\
\end{array}$ & $\begin{array}{l}\text { Early } \\
\text { yield }\end{array}$ & $\begin{array}{c}\text { Total } \\
\text { phenol }\end{array}$ \\
\hline Disease severity on crown & - & - & - & - & - & - \\
\hline Early yield & $\begin{array}{c}-0.747^{* a} \\
0.033^{\mathrm{b}}\end{array}$ & - & - & $\begin{array}{c}-0.759^{* a} \\
0.029^{\mathrm{b}}\end{array}$ & $\begin{array}{c}-0.759^{* a} \\
0.029^{\mathrm{b}}\end{array}$ & - \\
\hline Total phenol & $\begin{array}{c}-0.231^{\mathrm{a}} \\
0.583^{\mathrm{b}}\end{array}$ & $\begin{array}{l}0.06^{1 \mathrm{a}} \\
0.886^{\mathrm{b}} \\
\end{array}$ & - & $\begin{array}{c}-0.246^{\mathrm{a}} \\
0.557^{\mathrm{b}}\end{array}$ & $\begin{array}{c}-0.246^{\mathrm{a}} \\
0.557^{\mathrm{b}}\end{array}$ & - \\
\hline
\end{tabular}

${ }^{\mathrm{a}}$ linear correlation coefficient(r) is significant at the 0.05 level, ${ }^{\mathrm{b}}$ probability level.

Egypt. J. Phytopathol., Vol. 47, No. 2 (2019) 
There was a strong correlation between the disease severity on root, the disease severity on crown and early harvest of fruits (Table 9). A significant positive correlation was noticed between disease severity on root and disease severity on crown in the first season, being $(r=0.995, p=0.000)$. The percentage of disease severity on root was inversely proportional with each of the percentage of disease severity on crown and early harvest for both two seasons.

Table (9): Coefficients of correlation between disease severity on root, disease severity on crown and, early yield of strawberry fruits.

\begin{tabular}{|c|c|c|c|c|c|c|}
\hline \multirow[b]{2}{*}{ variables } & \multicolumn{3}{|c|}{$2017 / 18$} & \multicolumn{3}{|c|}{$2018 / 19$} \\
\hline & $\begin{array}{l}\text { Disease } \\
\text { severity } \\
\text { on root }\end{array}$ & $\begin{array}{c}\text { disease } \\
\text { severity } \\
\text { on crown }\end{array}$ & $\begin{array}{l}\text { Early } \\
\text { yield }\end{array}$ & $\begin{array}{c}\text { Disease } \\
\text { severity } \\
\text { on root }\end{array}$ & $\begin{array}{c}\text { disease } \\
\text { severity } \\
\text { on crown }\end{array}$ & $\begin{array}{l}\text { Early } \\
\text { yield }\end{array}$ \\
\hline disease severity on root & - & - & - & - & - & - \\
\hline disease severity on crown & $\begin{array}{c}0.995^{* * a} \\
0.000^{\mathrm{b}}\end{array}$ & - & - & $\begin{array}{c}0.998^{* a} \\
0.00^{\mathrm{b}}\end{array}$ & - & - \\
\hline Early yield & $\begin{array}{c}-0.797^{* a} \\
0.018^{\mathrm{b}}\end{array}$ & $\begin{array}{c}-0.747^{* a} \\
0.033^{\mathrm{b}}\end{array}$ & - & $\begin{array}{c}-0.791^{* a} \\
0.019^{\mathrm{b}}\end{array}$ & $\begin{array}{c}-0.759^{* a} \\
0.029^{\mathrm{b}}\end{array}$ & - \\
\hline
\end{tabular}

${ }^{\mathrm{a}}$ linear correlation coefficient( $(\mathrm{r})$ is significant at the 0.05 level, ${ }^{\mathrm{b}}$ probability level.

\section{Discussion}

Still using pesticides in controlling plant diseases is a common practice especially in the developing countries. However, application of chemical fungicides has dangerous effects on human health and environment as well. Moreover, with their excessive and misuse, applications with fungicides may lead to emerging of resistance pests (O'Brien, 1994).

In the present research, effect of applying two plant extracts (garlic and radish) and jojoba oil at different concentrations $(5,10$ and 15\%) on the linear growth of $F$. solani, M. phaseolina and $R$. solani the causal agents of strawberry crown and root rot diseases was investigated under lab conditions. Obtained data indicated that radish and garlic extracts caused the highest suppressive effect on the linear growth of the three pathogens when each of them was added to the medium at all the tested concentrations. At $15 \%$ concentration they completely inhibited the growth of $M$. phaseolina and R. solani. F. solani was the least affected one. According to Avato et al. (2000) effect of garlic extract might be due to that garlic extract can comprise secondary metabolites and some of them as well as their derivatives have antimicrobial effect such as phenolic compounds, which may sensitize the phospholipids which hinder the movement of fungi as also mentioned by ElMetwally et al. (2010). Garlic extracts have been shown to contain at least several biologically active compounds and this diversity of compounds may account for the garlic extract's ability to affect a wide range of soil borne fungal pathogens (Kyung and Lee, 2001). As for radish extract, Javaid and Bashir (2015) stated that its effect might be due to the presence of cysteine-rich peptides (Rs-AFP1 and Rs-AFP2), 
RAP-1 and RAP-2 protein, cafeic, ferulic and phydroxybenzoic acid. At the same time Rani et al. (2008) and Hassan et al. (2016) proved that radish has volatile compounds including isothiocyates that induce the hydrolysis of glucosinates (four types of the glucosinolate compound including glucoraphanin, dehydroerucin, glucobrassicin, and glucoerucin) which are responsible for its antifungal toxic effects on the pathogens and decrease the incidence of various diseases. Jojoba oil came at third place in reducing linear growth of the pathogenic fungi. Its effect might be due to that it contains wax esters, which are derived from esterification of monoethylenic acids and monoethylenic alcohols, these compounds block the movement of the pathogenic fungi (Hicks, 2001). Obtained results during the progress of the present investigation are in agreement with those reported by Hicks (2001), El-Mougy and Abdel-Kader (2007) and Javaid and Bashir (2015).

Effect of drenching soil of strawberry transplants with plant extracts and jojoba oil on the disease severity of crown and root rots compared to fungicides treatment was investigated under both nursery and field conditions during two successive seasons. It was shown that applying plant extracts and jojoba oil singly or in combinations significantly reduced disease severity of crown and root rots compared to control and approaches the results obtained with fungicides and that was obvious in both nursery and field trials. These results are in harmony with those obtained by El-Mougy and Abdel-Kader (2007), Hussien, (2011) and Soliman et al. (2013). At the same time, applying plant extracts reduced the percentage of lost transplants emerging from the nursery in addition to significantly improved different growth parameters of these transplants.

Results of the present study also revealed that the tested plant extracts and jojoba oil significantly increased early and total yield of strawberry fruits. This result might be due to the influence of plant extracts on the improvement of transplants vigor which leads to getting strong plants giving more yield compared to control treatment. The growth improvement in strawberry plants can be understood as mentioned by Puvaca et al. (2014) and Martins et al. (2016). The fact that garlic extracts contain various growth-promoting compounds such as starch and vitamins and organosulphur compounds such as allicin and diallyldisulphide. Several reports represented an increase in plant growth by using garlic extract, for example, increase in the number of flowers in summer squash cv. Eskandarani (Helmy 1992). Similar results on squash were also obtained by El-Desouky et al. (1998). In addition, garlic extract caused a great increase in the number of pods of pea plants (Ahmed et al., 2005). Likewise, Sikandar et al. (2018) stated that garlic extract treatment increased the growth parameters of pepper plant.

Some features of biochemical responses in strawberry plants due to the application of plant extracts were studied in this investigation. It was found that treating strawberry plants with radish extract was the best treatment in increasing significantly total phenols. In addition, the tested plant extracts and jojoba oil

Egypt. J. Phytopathol., Vol. 47, No. 2 (2019) 
increased significantly free phenols. Moreover, there was a strong correlation between the disease severity on root, early yield and total phenols. The present results concerning the increase in total phenol contents are in agreement with those reported by several previous investigations who mentioned that increase in phenol levels after applying plant extracts including garlic and radish and jojoba oil (Lozano et al., 2000; Abd El-Moniem, 2001; Ahmed, 2004; Javaid and Bashir, 2015 and Sikandar et al., 2018). On the other hand, applying plant extracts or jojoba oil did not affect fruit firmness although they significantly affected anthocyanin pigments in the first season (only with radish extract treatment).

Many researches on bio-active plant extract emphasized on the effect of sole plant extract against plant pathogens or diseases and few researches tried to test different combinations or mixtures of plant extracts. Obtained results from this study revealed that applying double or triple mixtures of plant extracts or in addition with jojoba oil was more efficient than single application and that was obvious in all the growth parameters taken into consideration and it approaches the results of using fungicides.

\section{Conclusion}

Results of the nursery and field trials suggest that radish seed and garlic cloves extracts in addition to jojoba oil may provide an inexpensive and effective method for controlling strawberry crown and root rots in commercial production. At the same time, these treatments could be used with fungicides or as alternatives in integrated pest management programs (IPM) of soil borne diseases of strawberry.

\section{References}

Ahmed, G.A. 2004. Using plant extracts to control powdery mildew disease that attack cucumber plants under protected houses. M.Sc. Thesis., Zagazig City: Zagazig University, Benha Branch, 200 pp

Ahmed, S.; Iqbal. J. and Attauddin, I. 2005. Time of application effect of phytobiocides on powdery mildew and yield in pea. Sarhad J Agric., 21: 729731.

Avato, P.; Tursi, F.; Vitali, C.; Miccolis, V. and Candido, V. 2000. Allysulfide constituents of garlic volatile oil as antimicrobial agents. Phytomedicine, 7: 239-243.

Abd El-Moniem, M.L. 2001. Evaluation of some non-chemical methods to control some soil borne fungi and foliage diseases of cucumber. Ph.D. Thesis. Fac. Agric., Zagazig Univ., 143 pp.

Bhardwaj, S.K. 2012. Evaluation of plant extracts as antifungal agents against Fusarium solani (Mart.) Sacc. World Journal of Agricultural Sciences. 8(4): 385-388. 
Burkhart, L. 1943. Firmness of strawberries as measured by a penetrometer. Plant Physiol., 18: 693-698.

De Cal, A.; Martinez-Treceno, A.; Lopez-Aranda, J.M. and Melgarijo, P. 2004. Chemical alternatives to methyl bromide in Spanish strawberry nurseries. Plant Dis., 88: 210-214.

Dewidar, A.A.1.; Kenawy, A.G.M.1 and Ghebrial, E.W.R. 2019. Influence of different garlic treatments on controlling basal stem rot, root rot and infection by Broomrape in geranium plants. Egypt. J. Phytopathol., 47(1): 347-366.

El-Desouky S.A.; Wanas L.A. and Khedr Z.M. 1998. Utilization of some natural plant extracts of garlic and yeast as cloves-soaking materials to squash (Cucurbita pepo L.). I. Effect on growth, sex expression and fruit yield and quality. Ann Agric. Sci. Moshtohor, 36: 839-854

El-Metwally, M.A.; Ghanem, K.M. and Abd El-Hai, K.M. 2010. Improving the performance of faba bean and controlling of chocolate spot disease using biocompounds. Plant Pathol. J., 9: 169-178.

El-Mougy, N.S. and Abdel-Kader, M.M. 2007. Antifungal effect of powdered spices and their extracts on growth and activity of some fungi in relation to dampingoff disease control. J. Plant Protect. Res., 47 (3):266-278.

El-Sharkawy, R.M.I. 2006. Studies on root-rot and wilt disease of strawberry with special reference to their control in Egypt. Ph.D. Thesis, Fac. of Agric. AlAzhar Univ. Egypt, 194pp.

Errifi, A.; Ouazzani, T.A.; Mouden, N.; El Batnan, A.M.; El Hazzat, N. Selmaoui, K.; Benkirane, R. and Douira A. 2019. Pathogenicity of Rhizoctonia solani towards distinct varieties of cultivated strawberry plants in Morocco. Plant Cell Biotechnology and Molecular Biology, 20(23\&24): 1086-1099.

Fawzi, E.M.; Khalil, A.A. and Afifi, A.F. 2009. Antifungal effect of some plant extracts on Alternaria alternata and Fusarium oxysporum. African Journal of Biotechnology, 8(11): 2590-2597.

Fokemma, N.J. 1973. The role of saprophytic fungi in antagonism against Drechslera sorokiniana (Helminthosporium sativum) on agar plates and on rye leaves with pollen. Physiol. Plant Pathol., 3: 195-205.

Fuleki, T. and Francis, F.J. 1968. Quantitative methods for anthocyanin. 1. Extraction and determination of total anthocyanin in cranberries. J. Food Sci., 33: 72-77.

Gnanamanickam, S.S. 2002. Biological control of crop diseases. Marcel Dekker Inc., New York, USA, 468 pp.

Egypt. J. Phytopathol., Vol. 47, No. 2 (2019) 
Gutiérrez, R.M.P.; Perez, R.L. 2004. Raphanus sativus (Radish): Their Chemistry and Biology. Sci. World J., 4: 811-837.

Hassan, A.K.; Kareem, T.A. and Matar, S.S. 2016. Effect of bio fumigation with radish (Raphanus sativus) leaves fresh and seed meals to control root knot nematode and Fusarium wilt disease complex infecting eggplant. Journal of Biology, Agriculture and Healthcare, 6(4):21-25.

Helmy, E.M.S. 1992. Response to summer squash application methods of fresh garlic extracted by different solvents. Alex. J. Agric. Res., 37:125-142

Hicks, S.C. 2001. Method of controlling powdery mildew infections of plants using jojoba wax. Espacenet Patent Search. Bibliographic Data: US6174920 (B1), pp. 1-12.

Horsfall, J.G. and Barratt, R.W. 1945. An improved grading system for measuring plant disease. Phytopathology, 35: 655- 657.

Hussien, Z.N., 2011. New approaches for controlling peanut root rot and pod rots caused by Rhizoctonia solani in Egypt and Nigeria. Ph.D. Thesis. African Research and Studies Inst., Cairo Univ., pp: 138.

IBM., 2010. IBM SPSS Statistics for Windows, Version 19.0 IBM Corporation, Armonk, New York.

Jalili-Marandi, R.; Hassani, A.; Ghosta, Y.; Abdollahi, A.; Pirzad, A. and Sefidkon, F. 2010. Thymus kotschyanus and Carum copticum essential oils as botanical preservatives for table grape. Journal of Medicinal Plants Research, 4(22): 2424-2430.

Javaid, A. and Bashir, A. 2015. Radish extracts as natural fungicides for management of Fusarium oxysporum f. sp. lycopersici, the cause of tomato wilt. Pak. J. Bot., 47: 321-324

Kuruchve, V. and Padmavathi, R. 1997. Fungi toxicity of selected plant products against Pythium aphanidermatum. Indian Phytopathol., 50(4): 529-535.

Kyung, K.H. and Y.C. Lee. 2001. Antimicrobial activities of sulfur compounds derived from S-alk(en)yl-L-cysteine sulfoxides in Allium and Brassica. Food Rev. Int., 17: 183-198.

Lozano, T.C.; Cordoba, S.N.; Avila-de-Moreno, C.; Velosa, R.M. and de Moreno, C. 2000. Evaluation of the effect of hydrolates of garlic (Allium sativum) and welshonion (Allium fistulosum) on the development of the phytopathogenic fungi Botrytis allii and Sclerotium cepivorum. Fitopatologia-Colombiana, 24: 29-32. 
Martins N.; Petropoulos, S. and Ferreira, I.C.F.R. 2016. Chemical composition and bioactive compounds of garlic (Allium sativum L.) as affected by pre- and post-harvest conditions: A review. Food Chem., 211: 41-50.

Mercado, W. and R.P. Rodriguez. 2001. Fungicidas para el manejo del cancro y lapudricion de raiz de los cafetos. J. Agr. Univ. Puerto Rico., 85: 187-195.

Mosa, O.M.; Soliman, N.E.K. and Tolba, A.F. 2013. Evaluation of different mixtures of bioagents and antioxidants with bioagents on root rot in strawberries. Egypt. J. Phytopathol., 41(1): 109-119.

O’Brien, R.G. 1994. Fungicides resistance in populations of cucurbit powdery mildew (Sphaerotheca fuliginea). New Zealand J. Crop Hortic. Sci., 22: 145149.

Osman, N.A.I.; Hanafi, A.A.; El-Deeb, A.A. and Abdel-Magid, M.S. 1996. Effect of garlic extract and volatiles on root rot and pod rot diseases of peanut (Arachis hypogaea L.). Egypt J. Appl. Sci., 11(10): 162-175.

Pastrana, A.M.; Capote, N.; De los Santos, B.; Romero, F. and Basallote-Ureba, M.J. 2014. First report of Fusarium solani causing crown and root rot on strawberry crops in Southwestern Spain. Plant Disease, 98(1): 161.

Puvaca, N.; Ljubojević, D.; Lukač, D.; Borojević, M.; Kostadinović, L.; Teodosin, S. and Stanaćev, V. 2014. Bioactive compounds of garlic, black pepper and hot red pepper. In: Proc XVI Int. Symp., "Feed Technology". Novi Sad, Serbia, pp 116-122.

Raja, J. and Kurucheve, V. 1999. Influence of plant extracts and buffalo urine on the growth and sclerotial germination of Macrophomina phaseolina. Indian Phytopathology, 51(1): 102-103.

Rani, I.; Akhund, S. and Abro, H. 2008. Antimicrobial potential of seed extract of Raphanus sativus. Pak. J. Bot., 40: 1793-1798.

Reyad, N. and Attia, M.F. 2016. Management of Zinnia powdery mildew using safe alternatives to fungicides. Egypt. J. Phytopathol., 44(1): 134-155.

Romanazzi, G.; Lichter, A.; Gabler, F.M. and Smilanick, J.L. 2012. Recent advances on the use of natural and safe alternatives to conventional methods to control postharvest gray mold of table grapes. Postharvest Biology and Technology, 63: $141-147$.

Sanchez, S.; Henriquez, J.L.; Urcola, A.; Scott, A. and Gambardella, M. 2016. Susceptibility of strawberry cultivars to root and crown rot caused by Macrophomina phaseolina. J. Berry Res., 6: 345- 354.

Egypt. J. Phytopathol., Vol. 47, No. 2 (2019) 
Senedecor, G.W. and Chocran, W.G. 1989. Statistical Methods, $8^{\text {th }}$ Ed. Iowa State Univ. Press, Ames, Iowa, USA. 524pp.

Shaban, W. 2015. Evaluation of some fungicide alternatives against Alternaria fruit rot on tomato. Egypt. J. Phytopathol., 42(2): 91-104.

Shehata, M.M. 2007. Studies on some strawberry diseases in nurseries. Ph.D. Thesis, Al-Azhar University, Egypt. 190 pp.

Sikandar, H.; Ahmad, H.; Ali, M.; Kashif, H.; Khan, M.A.; Cheng, Z.; Smith, F.M.A.; Gilles, J.K. and Hamilton, P. 2018. Aqueous garlic extract as a plant bio stimulant enhances physiology, improves crop quality and metabolite abundance, and primes the defense responses of receiver plants. Appl. Sci., 8(5): 15 .

Simons, J.T. and Ross, A.F. 1971. Changes in phenol metabolism associated with systemic resistance to tobacco mosaic virus in Samsun NN tobacco. Phytopathology, 61: 1261-1265.

Singh, A.K. 2008. Efficacy of plant extracts for the control of powdery mildew of coriander (Coriandrum sativum L.). J. Spices and Aromatic Crops, 17(1): 2425.

Singh, P.; Singh, J. 2013. Medicinal and therapeutic utilities of Raphanus sativus. Int. J. Plant Anim. Environ. Sci., 3: 103-105.

Soliman, N.K.; Saber, M.M. and Ahmed M.F.A. 2013. Evaluation of some plant extracts on controlling damping-off and root-rot diseases of bean (Phaseolus vulgaris L.). Egypt. J. Phytopathol., 41(1): 185-198.

Thomas, W. and R.A. Dutcher, 1924. The colorimetric determination of carbohydrates in plants by the picric acid reduction method 1 . The estimation of reducing sugars and sucrose. J. Am. Chem. Soc., 46: 1662-1669.

Tohamy, M.R.; Aly, A.Z.; Abdelmoity, T.H.; Attia, M.M. and Abdelmoniem, M.L. 2002. Evaluation of some plant extracts in control damping-off and mildew diseases of cucumber. Egypt J. Phytopathol., 30(2): 71-80.

Zaker, M. 2016. Natural plant products as eco-friendly fungicides for plant diseases control: A Review. The Agriculturists, 14(1): 134-141.

Corresponding author: Soliman, M.S.

E-mail: maali_soliman@yahoo.com

(Received 25/09/2019;

in revised form 29/10/2019) 


\section{قدرة النشاط التضادى لاثنين من المستخلصات النباتية وزيت الجوجوبا ضد الفطريات المسببة لأعفان التاج والجذر في الفراولة}

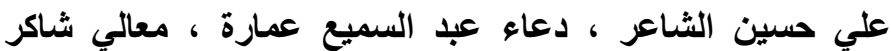
سليمان ، إيمان يحي خفاجي ،و شيرين السيد محمد النحاس ، دعاء

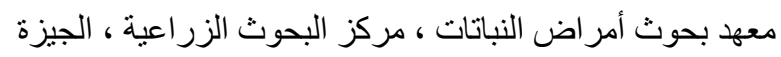

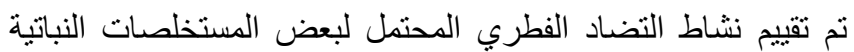

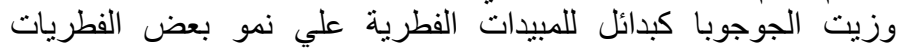

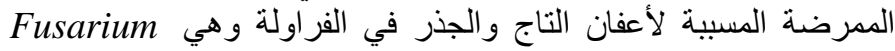
Rhizoctonia solani و Macrophomina phaseolina g solani

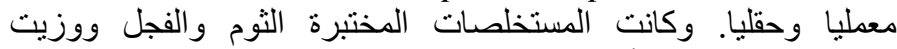

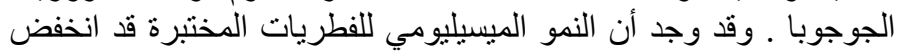

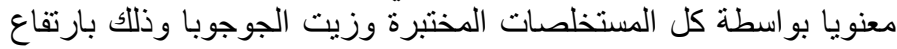

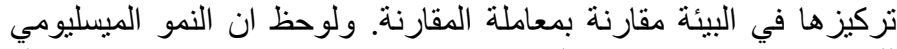

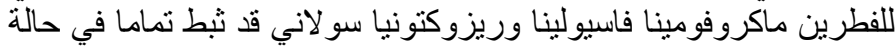

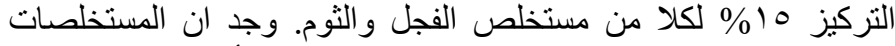

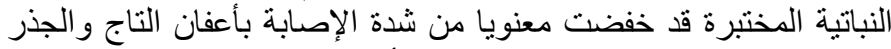

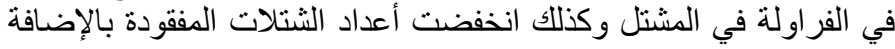

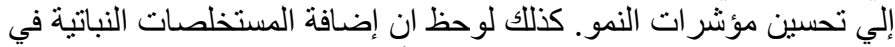

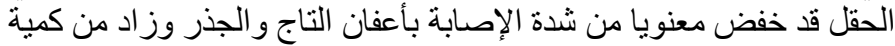

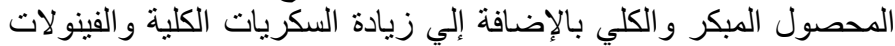

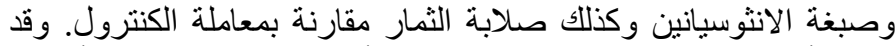

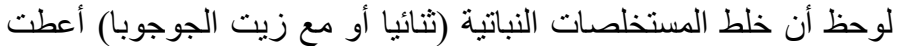

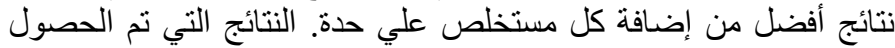

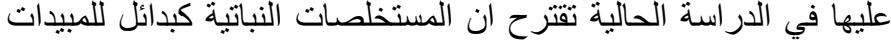

الفطرية تعتبر طريقة واعدة لمقاومة فطريات التربة الممرضة للفر اولة. 